\title{
Anxieties of Embodiment
}

\author{
Liveness and Deadness in the New Dispensation
}

"The song is in front! The picture is in the back!" exclaimed the headline of an article in Bommai magazine in 1975 (Bommai 1975a). The article described a new kind of program that presented a singer onstage with the song scene from the film projected behind him as he sang. This was one variant of a new performance genre, the live show put on by professional mellicai külukkal (light music troupes). The term mellicai (light music) was coined in the late 1950 s to cover forms of music that fell outside of what was considered classical. By the 1970s, it had also come to connote a "modern" performance style and form of entertainment: a felicitous combination of Indian musical elements and Western instruments, orchestration, and performance practices (see fig. 14). Stage shows of light music became so popular in Madras in the 1970s that, as the article commented, "every day there is a new troupe that puts on light music programs of film songs."

The article's exclamatory headline registered the striking reversal effected by this new configuration in which the singer was displayed for all to see. Playback, by definition, had established the studio, not the stage, as the privileged origin of the song. Not only was the originary moment for the visual scene in the film the playing back of the recorded voice; the ideal stage performance was also understood to be a reproduction of the original created in the studio. But even more salient was the moral distinction between studio and stage. The studio, in the decades of playback's heyday, was governed by hierarchical social relations: a space controlled by male music directors, film directors, and producers, in which women singers' participation was carefully controlled and limited. The studio mediated, and thus rendered respectable, the interaction between female singers and the mass audiences who would hear their voices in films. The stage, in contrast, was tainted by its association with immodest public display, irrevocably associated with women outside the norms of respectability (embodied most 


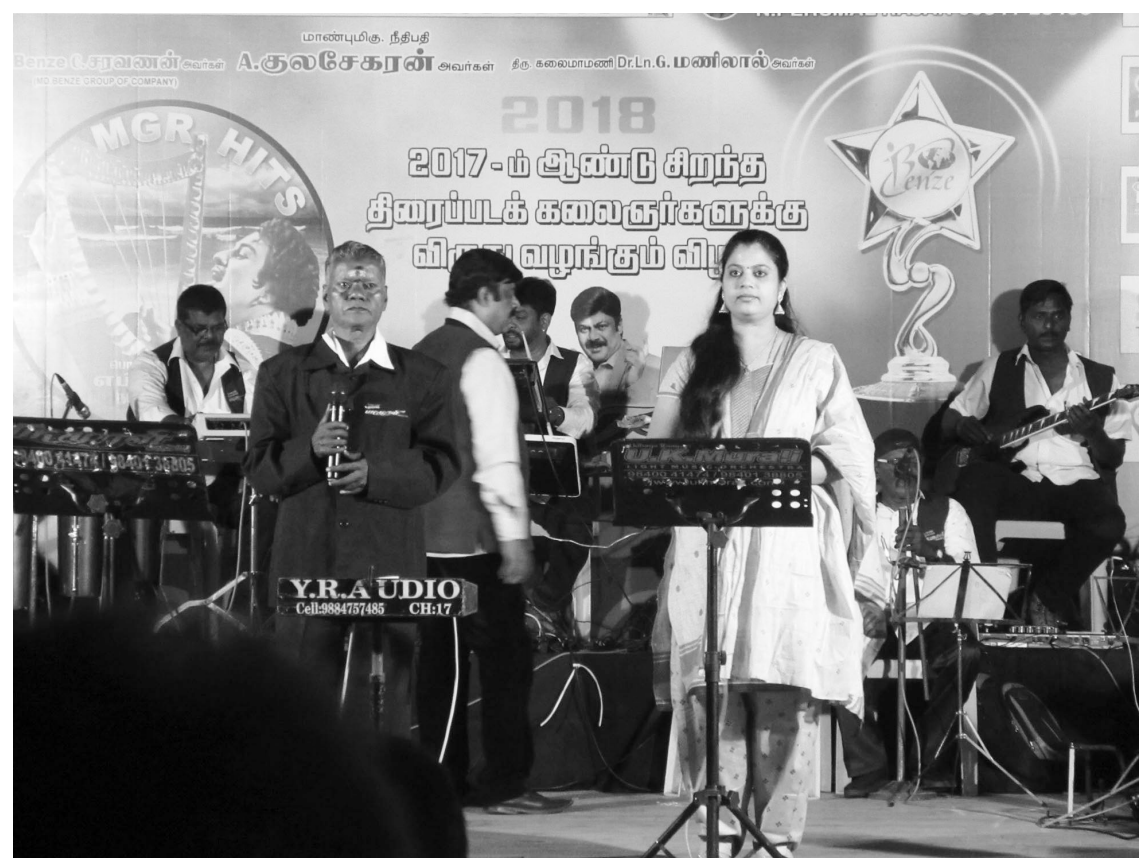

FIGURE 14. Troupe singers preparing to imitate T. M. Soundararajan and P. Susheela in a performance with U. K. Murali’s light music troupe, Chennai, Jan. 2018. Photo by author.

paradigmatically by the cabaret singer/dancer character often portrayed in films of the 1950 s and 1960s). As we saw in chapter 3, when respectable singers like Susheela or Janaki did perform, they took care to make their stage performance just like the act of singing into a microphone in the studio, downplaying the conditions of live performance, such as the visibility of their own bodies and the presence of the audience, as much as possible.

Anthropologically oriented performance studies, ethnomusicology, and sound studies scholarship have countered the idealization of the stage and studio as spontaneous sites of performance or creativity, recognizing them as socially and culturally inflected spaces (Seizer 2005; Meintjes 2003, 2017; Porcello 2004; Bates 2012, 2016). Building on their insights, in this chapter, I engage ethnographically with the stage and the studio, moving from the 1970s into the new performative dispensation of the post-liberalization present, in which the "moral and aesthetic assurances" of the previous decades are no longer reliable (Mazzarella 2013, 69). Within this new dispensation, both stage and studio have shifted from being governed by clear gender norms and hierarchies to being imagined as spaces of greater freedom, spontaneity, and self-expression. This transformation has been imagined in part as a move toward greater "liveness," a quality that has become increasingly enregistered as a positive value in India's post-liberalization era (Mazumdar 2013). 
In everyday usage, the term live refers to a performance or event that takes place in the same time and space as its reception and is most commonsensically opposed to something that has been "recorded." Sound engineers and recordists may speak of the "liveness" of a sound as a function of its audible resonance in space, but liveness also depends on social resonance: either the actual or suggested presence of others. The opposite of "liveness" in this sense is "deadness." In sound recordists' parlance, "dead" sound is that which has been isolated (in the "dead," nonreverberant space of the studio) so that there is no reverberation or extraneous sound, enabling the qualities of the sound to be manipulated after the recording has been made.

While liveness is associated with collective audition and the imprint of space, and deadness with individuated, private, technologically enabled audition, liveness and deadness are not simply by-products of live performance or technologically mediated listening. Rather, they are deliberately produced effects or sensations that can be produced in both a face-to-face performance and a recording (Novak 2013, 48-50; see also Auslander 2008; Wurtzler 1992; Keightley 1996). For instance, a recording can be made to sound more "live" or more "dead," depending on the amount of reverb or other spatial indicators inserted into or removed from the mix (Doyle 2005). Similarly, a live performance can, in fact, rely on the mediation of multiple technologies to produce a sense of its liveness or on particular performance practices or specially designed architecture to make it seem more dead. For example, both the use of architectural design to reduce reverberation in American concert halls in the early twentieth century (Thompson 2002), and the use of bodily stillness and downcast eyes by playback singers onstage in the 1960 , 1970 , and 1980 os to remove them from the scene of performance, were techniques for producing deadness, positively associated in the former context with bourgeois, individuated listening and in the latter with female respectability.

Rather than assuming that liveness or deadness are attributes of particular spaces or kinds of sound, I suggest here that they are better considered as signrelated phenomena, produced through the assemblage and manipulation of qualia that may be sonic, visual, haptic, or verbal. Their sensory aspects are endowed with social meaning and value as they are brought into relation with each other and with other salient oppositions - for example, public vs. private, old vs. young, traditional vs. modern, local vs. global, masculine vs feminine, and licit and respectable femininity vs. sexualized female presence. Taking liveness and deadness to be semiotic phenomena enables us to make sense of their simultaneous existence in both a technical register-describing types of sound or space-and a social register-describing the "feel" of a space or event. We can then ask, what values are attached to these qualities in particular contexts, and how are they mobilized for particular social projects? (see Novak 2013).

Whereas chapter 5 focused on the reorganization of values around qualities of vocal sound occurring in the post-liberalization period, this chapter considers a 
similar process of reorganization of values around the studio and the stage and their relationship to liveness and deadness. Playback, in its heyday during the 1960s, 1970s, and 1980s, constructed the studio as a live space, requiring musicians and singers to be copresent and positioned physically to produce desired sonic effects, in a quasi-public space of social interaction. Conversely, as I suggested above, the stage was constructed to be as "dead" as possible, deliberately minimizing or eliminating qualities of "live" performance such as movement, performeraudience interaction, and spontaneity. The deadness of the stage and the liveness of the studio, produced through contrasting assemblages of qualia, were valued and cultivated as a way of upholding the gendered social order.

Following the shifts in media ecology and performance aesthetics that occurred in the years after liberalization, the studio and the stage switched positions within this established contrast between liveness and deadness. In the 1990s, a new type of stage show emerged: high-budget, glitzy, English-medium affairs that emphasized visual spectacle and spontaneity rather than faithful reproduction of what had been recorded in the studio (Mazumdar 2013). For singers who came of age after the 1990s, the stage has come to be elevated as a place of self-expression and self-discovery, while the act of recording in the studio is seen as secondary, a mere necessity for making a living. The studio's deadness, however, is not simply negative. The numerous small, private, soundproof studios that have sprung up since the 1990 are also conceived as spaces of liberation from earlier social and musical norms.

To understand the gendered implications of these shifts, I attend to the extramusical aspects of singers' stage performances, such as their interaction with the audience, their dress and movement, and the general look of the stage, particularly in contexts where the older conventions of light music performance and the new ideals of performance in post-liberalization shows are in tension with each other. Similarly, in the second part of the chapter, I focus not on the content of studio work itself but on the social dynamics generated by the new spaces and their associated work process. In both cases, such details are the "indexical gestures" (Gal 2002) that work to produce sensations of liveness and deadness and endow them with socially salient meaning.

\section{MAKING LIGHT MUSIC RESPECTABLE}

Even as the public stage performance of film songs took on a standardized form with the emergence of light music troupes in the 1970s and 1980s, the relative privileging of the studio over the stage in moral terms persisted. Putting the singer in front-making what had been a musical performance that took place within the walls of the studio and remained behind the screen into a public stage performance-was not just a simple rearrangement. A. V. Ramanan, who founded the well-known light music troupe Musiano in Chennai in 1972, described what 
it took to develop a new style and "respect" for light music performance at that time. The mix of music that Musiano performed, including Western rock and roll hits, Hindi songs, Tamil film songs, and songs in Telugu, Kannada, Malayalam, and Punjabi, was meant to signify cosmopolitanism rather than low-class variety entertainment, an escape from provincial tastes and venues. The goal was, as Ramanan explained to me, "to bring a status to light music":

Back in the old days, I did road shows, temple programs. They would close off the street. I would go and ask, "Where is the stage?" "The stage is coming," they would say. And then a bullock cart would come dragging a platform, and another would come. They would join them and put a bedsheet over it, and that was the stage. They couldn't detach the bulls, so they would be there shitting and urinating during the performance. There would be three thousand people on either side. They didn't like me singing some songs. And I didn't like it. I decided when I start my own group I will not sing these kinds of programs.

Attracting the right kind of audience and educating them in the proper reception of film songs performed live was essential to conferring a licit and "modern" status on light music performances. It was crucial that audience members did not join in the performance or dance to the music; this was part of maintaining a professional distance between performers and audience. As Ramanan said, "We had captive [i.e., professional] singers. Not just the bridegroom's sister, not like that. They were singers performing only with Musiano. We wouldn't allow people to get up casually and sing with them ... and if people dance[d], we would stop the show. We are not singing to make you dance."

In the 1960s, singers performing film songs live had transitioned from sitting on the stage platform, as Karnatic singers did, to sitting on chairs on the stage. The chairs signified a kind of performance that was outside the hierarchies and conventions of Karnatic music but still kept the singer's body stationary. Standing, first with a microphone on a stand and later with a handheld mic, became the preferred practice for light music singers in the 1970s. Ramanan was the first to introduce the handheld microphone into South Indian performance contexts: "I revolutionized the whole thing. ... In those days [the 196os] the light music singers would all sit and sing. ... They would sit like a kutcheri [classical concert] and sing Karnatic style [imitates a Karnatic musician keeping tala, the cycle of beats marked by finger counts, claps, and hand waves]. I hated myself for sitting and singing like that."

Standing to sing located light music singers decidedly outside the bounds of traditional singing and more definitively within Western norms of performance. There was, however, a problem, for in Tamil films, such a mode of performance was usually associated with "club dances" performed by women of ill repute, in diegetic spaces frequented by villainous characters. Featuring a woman singing and dancing before an unknown male audience, the club represented the seamy underside of society that existed outside normative structures of family and kin. For light music to avoid these associations, there needed to be new kinds of singers 
and musicians who could project, as an award given to Ramanan in 1993 put it, "dignity" and "urbane refinement" onstage. A whole "bodily hexis" (Bourdieu 1977,93 ) connoting decency and respectability was needed to go along with the new standing posture:

AVR. I wanted to do something innovative. So I started picking up musicians who were [college] graduates. It took a long time.

Aw. Why graduates?

AVR. I wanted a minimum yardstick-it makes a difference how you conduct yourself as a musician. There will be some decorum with basic education. That's how I came to Uma's house.

Aw. What kind of decorum?

AVR. In families where they are not educated, or only up to tenth standard, they have this idea that girls can't go anywhere by themselves. Everyone in the family will come with the girl-her mother, her father, her uncle. If the girl is a little educated, she can be independent. ... I was looking for a woman who will carry herself well.

Uma had just finished her college degree. She had set her sights not on a career singing film songs but on a job as an air hostess, another position associated with cosmopolitanism and female independence. Uma described how, even though she had learned Karnatic music, she had to "learn the body language" to sing light music onstage: "how to use the hand mic, and how to use the standing mic, where you had to stand still-not too many body movements." She became known for her stage renditions of Susheela, Janaki, Lata Mangeshkar, and Asha Bhosle hits and also worked as a playback singer from 1975 onward. A feature on Uma in Femina magazine described her as "Madras' latest Lata Mangeshkar. . . . She stood before the mic, a modest sari-clad figure, the pallav covering her shoulders" (Femina 1975). After several years of working together, Uma and Ramanan married.

Standing, of course, allowed Ramanan to be "a complete showman," as an article written on the occasion of their receiving a government award remarked: "He is a live wire on stage while she is demure and distant. He ... jokes and quips and even clowns around a little if need be. She is quiet and still, not so much as swaying to the rhythm of the music and only allowing the golden notes to sail across the hall from time to time. ... Despite their dissimilarities or perhaps because each is such a fine foil to the other, A. V. Ramanan and Uma are a very popular duo" (The Hindu, April 11, 1997).

Enacting these gendered contrasts was part of projecting the dignity and refinement necessary for making the stage performance of film songs a socially acceptable form of entertainment that middle-class audiences would attend. The orchestra of smartly dressed men was, of course, important to producing a classy show. But the crucial element was the presence of the demure Uma, standing in for 
all female playback singers through her voicing of them, which would ratify this as a respectable form of entertainment. ${ }^{2}$

While the sound and aesthetics of the female voice changed in the 1970s and 1980 s, the female singer's conception of herself as "just the voice" did not. In fact, for singers like S. Janaki or Uma Ramanan, it was this steadfast maintenance of a division between voice and body, singing and acting, self and performance, as I described in chapter 3 , that made possible their vocal versatility by protecting their "self" from the myriad different characters their shifting vocal sound evoked. As live performances became more and more popular, this would become an indispensable strategy for female singers, one that drew on a more general set of conventions around performance and social class in the Tamil context, where excess movement onstage is traditionally read as lack of control, and bodily stillness is generally used to index higher-status personages (Seizer 2005, 77).

The claim to respectability through the bodily stillness of both performers and audience, the creation of a sense of professionalism through the distance maintained between the audience and the singers, and the maintenance of both male and female respectability through the gendered division of labor in performance were crucial strategies that mitigated the potential risks of presenting musicians and singers as entertainment and visual spectacle. Yet, since the shows by light music troupes were, and are, generally Tamil-medium productions presenting themselves as family entertainment (rather than catering to a "youth" audience), they faced the problem of how to respectably present female singers onstage. One strategy, as we have seen, was that of Ramanan and Uma: having the female singer be shielded not only by her modest, immobile body but by the presence of her husband on the stage next to her.

Being a "dedicated" female troupe singer who is not married to the troupe's leader, however, is a lower-status, vulnerable position. Covering playback singers' hit songs and singing supporting roles for the playback singers who are making guest appearances in the show, troupe singers not only have little choice about what they will have to sing but are also unknown, introduced only rarely by name in the live performances. Anonymity, in this case, is risky and undesirable because it provides no way to distinguish one's "self" from that which one is performing. At the same time, the dress code renders female troupe singers hypervisible onstage. While the male troupe singers always dress in the uniform of the troupe's instrumental musicians (all of whom are inevitably male), and are thus integrated into the corporate male group, the female troupe singers, dressed in salwar-kameez, are sartorially differentiated. This serves to uphold the troupe's respectability more than that of the singer, facilitating the necessary work female singers do on the stage while holding them at a distance. I was continually struck, in attending these performances, by how much the female troupe singers worked, singing in almost every number and covering all kinds of songs, all the while never being introduced by name onstage. Singing in such a state of combined anonymity and 
hypervisibility is especially risky when it is an item number that has to be performed. The only way to manage it is to stand stock still, with no expression on one's face-just the voice indeed!

\section{THE GIRLS ORCHESTRA}

It was to counter this kind of stigma attached to light music performance that the Chennai Girls Orchestra was launched in the year 2000. By its logic, overcoming the stigma meant not breaking entrenched gender roles but reversing them by creating a whole light music troupe composed of "girls," serving as both the musicians and the singers, who would change the gendered balance and look of the stage. ${ }^{3}$ Madhu M. M., the group's founder, described his idea to me: "I was in the light music field, as a singer. . . . One day I was thinking, in this orchestra why all these gents and just two girls singing. I just dreamt it. . . . Then I approached retired film musicians to see if they had daughters they had trained. . . . It was for uplift, it was social reforming work-that's how I looked at it. To show the women community, unkaḷālē muṭiyum [you too can do this]." 4

Madhu's discourse of social reform and uplift invokes nineteenth-century nationalist ideals of social change effected through the deliberate reengineering of societal institutions: change meant to show both the young women and society at large that a female-oriented light music show was possible. His use of the Tamil phrase "unkkậalē muțyum," however, indicates that, in these early millennial years, he was not just making room for any young women to perform as musicians but young women of a specific class, caste, and family background-connoted by the terms girls and orchestra, by his recruitment of girls from film families, and by his Tamil phrase addressing them-who were excluded by the new, glitzy, English-medium shows of the post-liberalization years.

Dressed smartly in matching shirts and pants, the Girls Orchestra began every performance with four or five girls standing in a line singing in unison their trademark introduction song, which paired the group's English name with a Tamil denotational gloss claiming distinction on a pan-Asian scale:

It's our turn, it's our turn

Asiāvin orē peṇkaḷ icai kūlu [Asia’s only girls' music troupe]

The Girls Orchestra, the Girls Orchestra

The presence of female musicians changed the visual effect, Madhu said, allowing female singers to go out onstage perumaiya $\bar{a}$ [proudly] and style- $\bar{a}$ [stylishly] —and here he imitated the stereotyped action of lifting one's collar with an aggressive gesture associated with mass heroes in Tamil cinema showing their dominance and command of a situation. ${ }^{5}$ Between 2000 and 2008 , the troupe presented more than a thousand shows specializing in Tamil film songs, performing all over Tamil Nadu and in Mumbai, Dubai, and Sri Lanka. 
But, despite its seeming success, maintaining the orchestra, as Madhu explained, required constant work because of the stigma associated with the light music stage: "If a girl got married, we'd have to replace her. . . Kalyānatukkappuram nī pōka kūtātu [after marriage you must not go], that is the mentality. . . . Handling the girls is hard. At every stage there is a problem. First is studying time, then job time, then marriage time, then again job time, then children. So girls nnā, eppōvumē tension [if it is girls, there will always be tension]. Our Tamil girls, they are locked in at every stage. They will say, 'Sir, I can't come today, my husband won't allow.'”

Tired of dealing with these difficulties, he had thought about getting "foreign ladies" as musicians, but that would have negated the orchestra's social reform project. For the point was that these were Tamil girls from non-Brahmin families (their non-Brahmin status coded by their "Tamilness" and the phrase "film families") who were onstage. Tamil girls playing the keyboard, the drums, and the tabla onstage enabled Tamil girls to dance around (if only modestly) onstage as they sang.

The Girls Orchestra adopted key visual and organizational elements of the light music troupe to protect its female performers and to accomplish its goal of "uplift" of the girls themselves and of their families. ${ }^{6}$ The visibility of the musicians and the group's corporate persona were essential; they were not a bunch of individual performers but professionals whose individual musicianship was subordinated to the group. The corporate nature of the group protected them from being recognized as individuals, clearly differentiating their stage presence from that of young female playback singers whose elevated class and caste position allowed them to perform in the glitzy, English-medium shows of the post-liberalization era.

\section{ROCKING THE STAGE}

In the early 1990s, a new mode of public performance was inaugurated, with shows featuring the live appearances of Bollywood film stars, catering primarily to diasporic audiences. The booming, buzzing extravaganza of these shows was a distinctly post-liberalization phenomenon, linking the desire for and promise of access to the star with transnational diasporic lives and capital. In the years since, these shows have come to be performed in India, as well, serving as important sites for generating value above and beyond the context of stars' appearances in films. A. R. Rahman's ascent to prominence since the early 1990 os marks the emergence of the music director as a "star" who performs his own songs in visually lavish shows.7 Such shows cultivate an aesthetic of liveness, produced through the appearance of the star as himself and by the spectacle of his accessibility, his contact with the masses of spectators (Mazumdar 2013). ${ }^{8}$ In these shows, Mazumdar observes, "rock star iconography is grafted on to the live performance of Indian stars through a play with technology, lighting, costume, and performance . . . [in] a mise-en-scene of music played at a high decibel level, dancing rays of light 


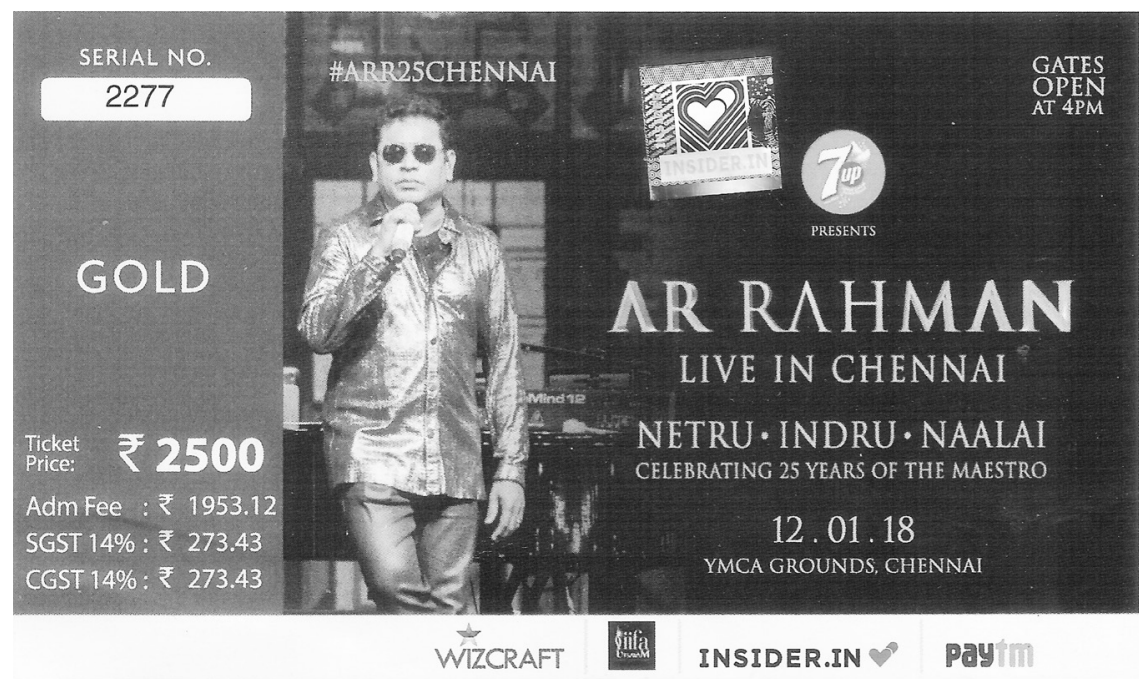

FIGURE 15. Music director A. R. Rahman pictured on a ticket stub for the show "Netru Indru Naalai," Chennai, Jan. 2018.

magically moving across the stage, and spontaneous acts performed both by the stars and the audience" (387).

In January of 2018, I attended Rahman's long-awaited live show, his first in Chennai since 2013, titled "Nettru indru naalai" (Yesterday, today, tomorrow), hyped as an emotional homecoming for the composer celebrating his twentyfive years in the film industry and major successes abroad. Entering the YMCA grounds in Chennai, an expanse of open space set back from the crush of traffic on Mount Road, I waited with thousands of others for darkness to descend. The main stage was surrounded by shaped side panels projecting close-up views of the performers, otherwise impossible to get for those in sections distant from the stage. Booming ads for $7 \mathrm{UP}$, the show's official sponsor, and the upcoming IIFA awards ceremony ${ }^{9}$ gave way to a dizzying explosion of light rays, and then the show started. Rahman appeared, glittering in a silver jacket, simultaneously tiny on his stage platform and huge in the octagonal side panels (see fig. 15). He strode around the stage as he began singing his hit songs from 1990 os films, and the audience went wild in a chorus of screams and cheers. Enormous shafts of light beamed in all directions, from stage to audience, audience to stage, and up to the sky, and the crowd raised their phones into the air to capture the moment.

Liveness, as I suggested earlier, is not simply a by-product of live performance; it is an effect, a strategically produced sensation of immersion and heightened presence, an "affective relationship between embodied experiences of the 'real' world and individual 'virtual' encounters with technological media" (Novak 2013, 32; see also Kim 2018). The star at the center of it is seemingly accessible but also 
larger than life, his image magnified and multiplied on numerous screens. The stages for these new kinds of performances, dark except for the special light effects, with large expanses for the singers to stride around in as they sing, present a striking visual contrast to the light music troupe's well-lit stage crowded with stationary musicians identically dressed in white suits. Unlike those subsumed within the corporate body of the light music troupe, musicians and singers in the new shows are visually magnified and individuated by the roving spotlights following their mobile bodies.

The January 2018 show appealed to this ideal of "liveness" in multiple ways. Though in their original filmic contexts they were sung by playback singers, here Rahman himself sang many of the songs. The presentation of the music director as the songs' deictic origo effaces the complex production format of film-song recording, where the music director may not compose, play, or even be present for the writing and recording of "his" songs. Part of the value that these shows offer to audiences is the fantasy of unmediated access to the authorial "source" of the music. In the January 2018 show, this was further accentuated by its ending with a prolonged instrumental jam session that stretched on until nearly midnight, featuring seemingly impromptu solo performances by the singers as well.

The young singers I talked with during my fieldwork in the first decade of the 2000 s and the early 2010 s tended to conceptualize the field of playback singing as divided between two types: "stationary singers" who "just take the mic and stand there looking at the lyrics," and "performance-oriented singers" who can "rock the stage" and "pull the crowd in." The singers A and B, mother and daughter, explained the shift in expectations that had occurred within a generation, between the 1970s and 1980s and the 2010s:

A. We used to sing without moving or anything. ... I am used to that culture. Of course we talk with the audience.... But still it looks odd if we move even a bit. We stand there, sing, and come back.... We are just a machine, it's just coming through our voices.... But they [the young singers] have to perform. They have to vibe with the audience. The stage shows are totally different now.

в. For my mom's performance, the audience, they know what they are coming for. They are not expecting her to move around. When they are coming for a young generation concert they want to have fun, be entertained. When they are going for a senior musician's concert like my mom, they want to listen to the quality of the older music.... The audience wants those songs to be recreated just the way the record was. But when I do shows with my band, we try to make it groovy, and call it "shows," try to make it ... something everybody can tap their feet to.

In the contrast drawn by A and B, it is not just the role of singer that has changed from that of a stationary "machine" to that of a mobile "entertainer." The audience has also shifted from stillness to mobility (modestly invoked by B through the image of their tapping feet), from the expectation of "listening" to a technically 
accurate reproduction to a desire to witness and participate in spontaneous onstage creation. ${ }^{10}$

The stage is accordingly imagined differently. Rather than being at best a secondary place where the original recording is simply reproduced, and at worst a suspect site of cheap spectacle, it is now imagined positively as a locus of authenticity, originality, and self-realization. B described doing one's own live shows as an imperative for a young singer to prove her legitimacy "as a musician first" and then only a playback singer. As another young singer in his twenties at the time of our conversation in 2012 put it to me, "When I'm in the studio, it's like I'm just trying to get work done. . . But the stage is where you really let yourself go."

Letting oneself go, "rocking the stage," entails making one's body into a visible signifier of musical feeling. The singer Karthik was often cited as exemplary in this regard: striding around the full space of the stage, sometimes facing the audience, sometimes the musicians, crouching, leaping, and generally visibly "feeling" the music as he sang. But, as a young male singer told me, "There is a definite dearth of performance-oriented singers. . . Most are amazing singers, but they hold themselves back, just take the mic and stand there. That's the old way, the traditional way of singing." He described the new performance style as an "opening up." At stake here is not just "new" versus "old" but the successful citation of different sites of musical value, particularly genres of US and global pop such as electronic music, hip-hop, and progressive rock. "Opening up" refers not just to a performance style but to the way a singer or music director can align himself toward different, and presumably wider, musical horizons.

But, as this young male singer continued to explain, whereas having a hit song could transform a male singer into someone who could "rock the stage," female singers were more rigidly divided into "those who can and those who can't":

Some [female] singers probably don't want to open up. Some are having proper traditional values-they're not like "hey" [voicing an imagined casual address to a mixed-gender audience or group of interlocutors]. They can't do that, it doesn't come naturally to them.... So there are two groups of female singers, those who can and those who can't. Some of those who are really good onstage may not be great singers, but they present themselves really well. Even in male singers, there are those types. . . . But I feel that difference is a lot more for female singers. Some of them come from traditional values, some are married. They get a really awesome song and it's a hit, but they don't want to be someone else onstage. But for guys it's like, oh, I got a hit song, now I'm going to be somebody different onstage.

For female singers (as for actresses), marriage effects a change of status that sits uneasily with the transformative potential of a hit song, making them either unavailable for the ogling that might very well happen if they were to "rock the stage," or only embarrassingly so. The contrasting types of "those who can and those who can't" are both gendered and class-linked; that is, male singers can for the most part "rock the stage" unproblematically, but women need to be of a certain class status to do so. 
This is because the demand for presence onstage, magnified through technologically enhanced visibility and audibility, also entails a proportionally greater risk of exposure. During Rahman's January 2018 show, the singer Neeti Mohan sang "Koñcam nilavu," elongating and groaning out the word tēkam (body) in an even more extreme manner than the original rendition (see chapter 5). The cameras zoomed in on her, projecting huge close-ups of her face and dancing body on the multiple screens. Although she was shielded by the upscale character of the event and by her non-Tamil identity and generally fashionable image, and although she had taken care to frame her extreme vocal performance by a dress change from a floor-length gown to a black miniskirt and high heels just before the song, the projected close-ups generated a level of visibility and exposure that simply appearing onstage does not.

\section{BEING MORE THAN “JUST THE VOICE”}

In contrast to the young male singer's idea of performance as simply "opening up," a young female singer described to me a far more deliberate process. She remarked that though some singers were influenced by Western performance styles, it is really quite difficult to move and gesture like a Western pop star while singing a technically challenging Tamil film song. Because there were "no models of women who move around and sing," and no training in how to do it, she was "still experimenting" with how to present herself onstage.

Indeed, performing in this new dispensation entails not just naturally letting loose previously hidden emotion but a reeducation of bodily habitus, including movement and vocal production, as well as interactional style. Whereas older singers rarely spoke more than a few words onstage, highlighting their own shyness and disfluency when they did, the young singer's speaking voice is now part of his or her performing persona. The capacity to acknowledge the audience and to easily switch between singing and chatting is a central part of "rocking the stage" and accentuating the show's "liveness."

Young singers pepper their performances with greetings and exhortations to the audience in English: phatic utterances (Kunreuther 2006, 340; Jakobson $1987,66)$ such as "Hello Chennai!" or "Let's have some claps!" that function to signal the singer's interactive, rather than machinelike, presence and the connection between performer and audience. This speaking style and its particular mode of address are modeled on the global register of arena rock and pop-star stage banter but, also and more proximately, on that of the television veejays and radio jockeys, with their chatty, English-speaking style and fashionable clothes, who have emerged on India's FM radio stations and new TV channels since liberalization. The on-air speaking style that FM radio announcers began to cultivate in the 199os presented a contrast to the staid, formal speaking style that had dominated All India Radio in the decades before (cf. Kunreuther 2006). These new radio and 
TV personalities cultivate an informal, spontaneous, sometimes joking style of interaction with callers and audiences that transgresses previous norms of on-air formality and politeness, as well as norms of interaction with strangers (Nakassis 2016, 133-34; Gupta 2011).

This interactional aesthetic is distinctly gendered. While there are certainly male announcers and veejays, it is the female veejay/jockey who seems to occupy the extremes of this aesthetic, perhaps because her "opened up" language and interactional style contrast so drastically with what is considered "modest" public behavior for women. The female MC, ubiquitous in light music stage shows since the turn of the millennium, is an extension of this figure. Whereas light music shows would have previously had male MCs if they had any at all, the female MC has become indispensable in setting the tone for shows now, her bubbly persona achieved through her use of a distinct and identifiable register marked by fluid, fast speech, a large dynamic range, frequently and easily switching between Tamil and English, and direct address to the audience.

The MC's presence onstage can provide a necessary foil for a female singer, allowing the latter to maintain her own respectable gravitas. For example, during Susheela's appearance in 2009 at a "musical nite" sponsored by her trust fund, in which she was revealing the recipient of her fund's annual award, her diffident stage presence and hesitating speech contrasted markedly with the chatty volubility of the female MC who was compering the night's program. Delegating the role of entertainer to the MC allowed Susheela to maintain her own status as "just the voice."

The female MC's chatty presence can also be used to direct the audience to receive an act the right way, defusing tension and channeling the "sensuous provocation" of a performance to its proper "representational meaning" (Mazzarella 2013). Consider, for example, this moment, which occurred during a show devoted to the well-known male playback singer S. P. Balasubrahmanyam (SPB):

After singing several songs, SPB exits the stage for a break and a young singer comes on. Unlike the others, she is not introduced by name, and she is mobile, swaying as she sings and stumbling from side to side in front of the white-suited musicians of Lakshman-Sruthi's orchestra. She is singing the famous vamp song "Unnai kan têtutü" (My eyes are searching for you), originally sung by the nagarāni-the snake queen-after she is fed an intoxicating fruit by the hero in the 1955 film Kanavaney kankanda deivam.

In the original song sequence, of course, the onscreen performance and the voice are provided by two different people, with the hiccups provided by a third person. ${ }^{12}$ But here onstage this singer is doing it all herself. Her slurred words and stylized hiccups become progressively more exaggerated through the three-minute performance. Toward the end, she slowly sinks to the ground as if in a stupor, leaning on one elbow and drawing long, audible intakes of breath as she falls back with each hiccup. As she does so, the show's female MC comes out and stands right behind her, applauding 
over her head, while the singer continues her swooning performance for another thirty seconds. As soon as she is finished with the last word of the song, she gets up hastily and stands with the MC, who begins a quick barrage of praise for the performance, her loudness and volubility contrasting with the shy, one-word replies of the singer, whose name, we learn, is Vandana.

MC. Vandana Vandana Vandana vā vā vā! \{audience applause\}

Inta poṇnu nān rompa kuṭti vayicilēyirunta pākkirēen. Enta vayacilēyirunta pāṭa arampiccin̉ka?

Vandana \{timidly, softly\}. UKG-

MC. UKGliruntu pātarinika!

How old are you now?

Vandana: Thirteen-

MC. Thirteen years old! innum palā palā nnu ... inta tiramaiyāna kulantai nalla valaraṇum unkalōṭa ... manamāna pārttukirēēn.

Toțarntu SPB avarkalai mēțaikki alaikkum munpāka ...
MC. Vandana, Vandana, Vandana, hooray! \{audience applause\}

I have been seeing this girl from a very young age. From what age did you start singing?

Vandana \{timidly, softly\}. UKG[kindergarten]

MC. From $U K G$ you are singing!

How old are you now?

Vandana: Thirteen-

MC. Thirteen years old! May this skillful child grow up well to shine even more, with your [blessing] I am sincerely watching for that.

And continuing now before we invite SPB back onto the stage...

Plain text $=$ Tamil colloquial register

Italic text $=$ English words

$\underline{\text { Underlined text }}=$ Tamil formal/official register

- = speaking turn not followed by pause

Bold text $=$ emphasis

Vandana is quickly returned to a state of respectability by the MC's flood of words that name her, praise her "talent," and emphasize the fact that she is still a girl. The MC uses English and two identifiable registers of Tamil, a colloquial one that places her in a motherly or auntly relationship to the girl, and the other a formal register associated with political speaking and other official occasions, which she uses to mark off the end of the performance and move things along. 
Through the MC's talk, everyone is put in their proper place. The potential damage incurred by the unification of the singer's body and voice is repaired by the delegation of voice to the MC. This repair is accomplished through not only the denotational content but also the stylistic contrasts (between the MC's and Vandana's speech, and between the different registers of the MC's speech) packed into this brief moment, which together transform Vandana's potentially brazen appearance onstage into a performance of talent by an otherwise shy girl. The audience, including the eminently respectable ladies seated next to me, applauds: a fitting reaction to such a display of talent and one that completes the return of the singer and the whole occasion to normalcy.

The MC is not only a foil or a facilitator. For young singers, she can also be a model; in fact, several of the young female singers I interviewed had started out as announcers or interns for FM radio stations before getting into playback singing, citing the speaking skills they had learned in this role as useful for their stage appearances. Consider, for example, this scenario at a show in celebration of "Super Star" actor Rajnikanth's birthday on an evening in December of 2012:

Inside a cavernously large indoor auditorium in Chennai, the male musicians of U. K. Murali's light music orchestra are seated around the edge of the stage, against a backdrop of a large illuminated screen advertising Fair \& Lovely [a skin-lightening cream] as the sponsor for this "Super Star night," flanked by other large panel-screens given over to pictures of Rajnikanth and advertisements for other sponsors. Colored lights shine down from above onto the space at the middle of the stage, where, around 7:30 p.m., a pair of young MCs officially start the show. The female MC speaks in a high-pitched, very fast barrage of mixed English and Tamil. She exhorts the audience to give themselves a round of applause for coming, her voice rising to a crescendo of enthusiasm as she concludes.

$\begin{array}{ll}\text { Attanai pēr vantin̉kaṇna } & \text { That so many people have come, } \\ \text { thank you so very much } & \text { thank you so very much } \\ \text { uñkalakāka nīnka oru kai } & \text { I think you should all } \\ \text { tatțikkalām nān ninaikkirēn! } & \text { give yourselves a hand! }\end{array}$

As they leave the stage, a young playback singer enters, wearing a shiny gold sleeveless top and tight pants. She speaks in the same cadence as the female MC, attempting the same speed and crescendo of enthusiasm. 
Hello Chennai! How are you?

\{Audience whistles, cheers\}

Inaikki namma . . oru romba ...

oru arputamāna show,

oru arputamāna oru ennamo ...

super star avarkaḷoțu birthday

celebrate paṇna vantirukkōm

nān inta superstaroțu ōru

fanatic-ē sollalām

ava pāṭattai rompa pițikkum

so um . . . inaikki inta show-le

pāṭa rompa rompa sandoṣam ...

namma superstarukku

ōru periya $\mathbf{O}$ pōṭalāmā?

\{Audience whistles, cheers\}

Ōrē ōru suriyan, ōrē ōru

cantiran, ōrē ōru talaivā

atu namma superstar!

\{Audience whistles\}

Yah!
Hello Chennai! How are you?

\{Audience whistles, cheers\}

Today we ... a very ...

a rare show,

a rare a whaddya callit...

we have come to celebrate

Super Star's birthday

For this Super Star I am

a fanatic one might say

I really like his films

so ... um, today I am very very

happy to sing in this show...

for our superstar

shall we put a big 'O'?

\{Audience whistles, cheers\}

There's only one sun, only one

moon, only one leader

that's our superstar!

\{Audience whistles\}

Yah!

Italic text $=$ English

Bold text $=$ stereotyped phrase

$\ldots$. pause

Here the singer's attempt to keep up a steady banter, as an MC would, results in numerous awkward locutions and disfluencies that project her discomfort with speaking Tamil even as she identifies herself as that most Tamil of persons, a Rajnikanth "fanatic." Although her words profess her connection with the audience, her performance in the register of the MC highlights her difference from them, pointing to her own class position as upper middle class and English-educated: distinctly different from that of an imagined audience of Rajni fans and from that of the female troupe singer standing next to her, who is dressed modestly in a sari 
and never speaks to the audience. To do what she does onstage, the singer must not speak proper Tamil (Nakassis 2015). Her linguistic disfluency projects her as safely "other" in order to counteract the potential stigma of performing onstage in ways that exceed the limits of gendered respectability.

The only points where her Tamil speech is fluent are in her quotation of two stereotyped phrases, marked in the transcript above. Of these, "O Pōtalāmā" is particularly interesting; it refers to the semantically and syntactically ambiguous but suggestive phrase "O poț" popularized by a hit song from the early 2000 s in which the phrase, delivered in a guttural tone against a driving beat accompanied by a sexually suggestive gesture, was used to voice the item girl's lust for the hero. ${ }^{13}$ The overwhelming popularity of the song created an ongoing afterlife for the expression, including further sexualization as it was cited in another item number two years later, "Appadi podu" (from Gilli 2004), as well as normalization as it was used in a variety of contexts, including as the title of a TV gameshow for children and as an expression for showing one's allegiance to a leader. But here the singer reconfigures the expression in key ways that allow her to "mention" it without quite using it, suggesting an association between herself and the item girl while simultaneously speaking in the voice of the MC. By modifying $O$ with periya (big), she tames the unruly intransitiveness of pōtu (put), with its lustful connotations, rendering it a more defined transitive act to be accomplished collectively along with the audience. Her use of the modal auxiliary form -lām with pōtu reinserts the expression back into everyday speech, transforming it from a lustful command to a polite suggestion [shall we/may I put O?].

\section{EDUCATING THE AUDIENCE}

Transforming the stage into a space of licit live entertainment involves cultivating a new bodily and interactive style, not just for the performer but for the audience as well. While A. V. Ramanan, back in the 1970s, had sought to enforce stillness in the audience for his light music troupe, the new post-liberalization shows instruct the audience in how to respond in kind to interactive, chatty performers. For instance, at a New Year's 2010 stage show I attended in Chennai, playback singer Anuradha Sriram was featured in a special program featuring "romantic songs." Between songs and blaring advertisements for fancy consumer goods, the $\mathrm{MC}$ would call up a couple from the audience and ask whether they had a "love marriage or an arranged marriage," exhorting the couples not to be shy. After engaging in some banter about this topic, mostly in English, a couple would pick a slip of paper out of a bag to determine the next romantic song to be sung by Anuradha. The show, with Anuradha as its idealized voice, rendered the audience's involvement respectable through the concept of romantic love and its interpellation of them as cosmopolitan consumer-subjects. In a wedding concert held at the exemplary aspirational site of the then newly constructed five-star Leela Palace 
Hotel a few years later, Anuradha herself assumed the role of MC and singer, repeatedly encouraging bride and groom to dance and the reluctant guests to clap along and dance "even though it feels strange."

The tension between respectable audience involvement and uncontrolled enthusiasm that can turn into ogling, cat-calling, and male homosocial public display is palpable in many public shows now. The older rules of comportment for stage performers and audience-their restrictions and the protections they afforded-have been rendered tenuous by new expectations for interactive performance and audience involvement. Managing this tension requires careful direction of the audience. During her performance of the iconic song "Karuppu tān" (The color black, from Vetri kodi kattu 2000) at the 2010 New Year's show, Anuradha encouraged the audience to clap, which they did, loudly, prompting her to clarify: "no, no, I meant clap along with the music!" Later on in the same show, the MC introduced a second singer, Georginaa, a singer from a Tamil Christian background known for her "Western" songs:

MC. Ivan̉kalukku reṇṭu talent irukke, pāțittē āṭuvan̉ka, āṭittē pāṭuvan̉ka, so enjoy paṇnunka!" [She has two talents: while singing she dances, and while dancing she sings, so enjoy!]

(Georginaa, dressed in jeans, comes onstage.)

GEORGINAA. Happy new year to everybody!

(As she waits for the orchestra to get ready, she crosses herself, and then addresses the audience again.)

GEORGINAA. This song that I am singing, I want everybody to clap and enjoy the song with me.

(Audience claps, whistles)

GEORGINAA. (raising her hands over her head to clap). Ini oru sattam! [louder!]

(Audience claps, whistles and cheers loudly)

GEORgINAA. That's it. (Looks out into the audience and sees young men dancing at the back. She waves her hand at them encouragingly.) Ah, dance paṇuninka! [dance!]

Georginaa then launches into a performance of "Koñcam nilavu," interspersed with whoops and shout-outs to the audience.

Here, in contrast to an imagined normative gendered “Tamil” ideal, various signifiers of alterity-Christianity, romantic love, English-are used to open a classed space of cosmopolitan identity in which middle-class people can be exposed to sexuality, can watch the performance of an item number, without being incited into becoming lewd, uncontrollable subjects (see Mazzarella 2013). But the attempt is not quite successful. About halfway through the song, audience members begin 
craning their necks to watch a pair of young men dancing in synchronized gyration with each other at the back. Georginaa finishes, and one of the female troupe singers enters and begins singing the next song, the item number "Veccikkavā." ${ }^{14}$ The young men's dancing becomes progressively more raunchy and sexualized, even while the singer remains nearly motionless in her onstage performance.

The introduction of Georginaa, clearly a different type from Anuradha and announced as such, seemingly provides license for a kind of dancing that is not quite what the event is encouraging. Exceeding the framework of romantic love, it becomes instead an occasion for male homosocial public display (often described as "gents kumpal-ā āturatu"-men dancing in a "gumbal" [kumpal] or "pack"). Such dancing may be fun for the men but is seen as vulgar and embarrassing to female onlookers and therefore must be managed by having the unnamed troupe singer take over. The young men's lewd dancing threatens to transform the chronotope of reception into that of the street kūttu, precisely the kind of subaltern male space that the event has labored to frame itself against.

\section{THE STUDIO, FROM PUBLIC TO PRIVATE}

As the stage gained new status as a locus of freedom and authenticity in the years following liberalization, the studio also underwent a transformation in its physical layout, work processes, and social status. In keeping with the privatizing impulses and effects of liberalization, the studio, a space that had previously been considered public, came to be privatized-not primarily in economic terms but physically and socially.

As Susan Gal has suggested, the distinction between public and private is best conceived not through spatial or boundary metaphors but as a semiotic, or signrelated, phenomenon. In this view, '"public' and 'private' are not particular places, domains, spheres of activity, or even types of interaction." Rather, the sense of a space, event, or performance as either public or private is relationally achieved, and the more general distinction between public and private is established, through indexical gestures, such as the ordering of bodies in space and in relation to each other, particular utterances or voicings, and other sensuous aspects, both visual and aural, that suggest proximity or distance (Gal 2002, 80-81). Crucially, in this understanding, a space, event, or performance can be recalibrated through such indexical gestures, turned either momentarily or more lastingly from public into private or vice versa (Gal 2002, 82).

Prior to the 1990s, most song and background score recording for Tamil cinema had taken place in two major studios, AVM and Prasad, which were housed on sprawling campuses in Kodambakkam and Vadapalani, the traditional center of film production in the western part of Chennai. They had large recording theaters set up for full orchestras. To record a song, everyone-the orchestra, the singers, the music director, assistants, lyricist, and sound recordist-had to be present. The 
song would be recorded from start to finish. Work took place in established shifts that stretched from early morning to midday and from early afternoon to night. ${ }^{15}$

A sound recordist who had worked for AVM Productions in the 1960 s described to me how, before the advent of multitrack recording enabled the capacity to record each instrument, singer, and sound on their own track, the entire orchestra, sometimes as many as 130 musicians, as well as the singers, would be recorded together. One mic would record the entire orchestra, while another would be reserved for the singers. Balancing and mixing the sound was a matter of the sound recordist's careful arrangement of the musicians and singers in the physical space. If several playback singers were being recorded, he might have one stand six inches from the mic, another a foot away, one singing straight, another at an angle. Any special effects such as reverb had to be created during the recording process itself.

During this period, the large space of the studio, occupied by numerous musicians and other personnel brought together by the necessity of working collectively, constituted a kind of public. Though set apart from the outside world, the studio was contiguous with it in respect to social mores; it was quite literally a "live", reverberant space, inhabited by large numbers of people. Its "liveness" resulted from the resonance within it of a social, and particularly gendered, hierarchy. ${ }^{16}$ It was a distinctly male space, one in which men vastly outnumbered women and in which women's participation was strictly controlled and limited to that of singing; all technical, management, authorial, and other musician roles were filled by men (see fig. 16). While the men in this space enjoyed an easy sociality with each other, the presence of women called for more regulated and structured relations (see chapter 3 ). The clear age and gender hierarchy that separated young female singers from older male music directors and male orchestra musicians was certainly limiting, but it was also familiar, demanding modes of relating (modest deference, male chaperones to mediate) that would be required in any situation of contact with unrelated men.

The need for large orchestras was lessened as the new post-liberalization music directors dispensed with the string orchestra sound and more of the instrumental backing for songs began to be provided by aural material from sampling libraries and electronic musical equipment that could provide the sound of any instrument. Multitrack recording and digital editing capacities obviated the need for everyone to be present for a recording; instead, individual musicians and singers could now be recorded on their own tracks and mixed and edited later. As happened in many other parts of the world in the 1990s, these changes led to a marked decentralization as large recording studios became obsolete and many smaller home and basement studios opened up around the city (Meintjes 2003, 78).

As scholarship on recording studios has suggested, the physical setup of the modern studio itself-the separation of the performing space from the technical equipment and the regulation of what various actors in the studio can see and hear-has the potential to create unequal power relations (Meintjes 2003; Williams 


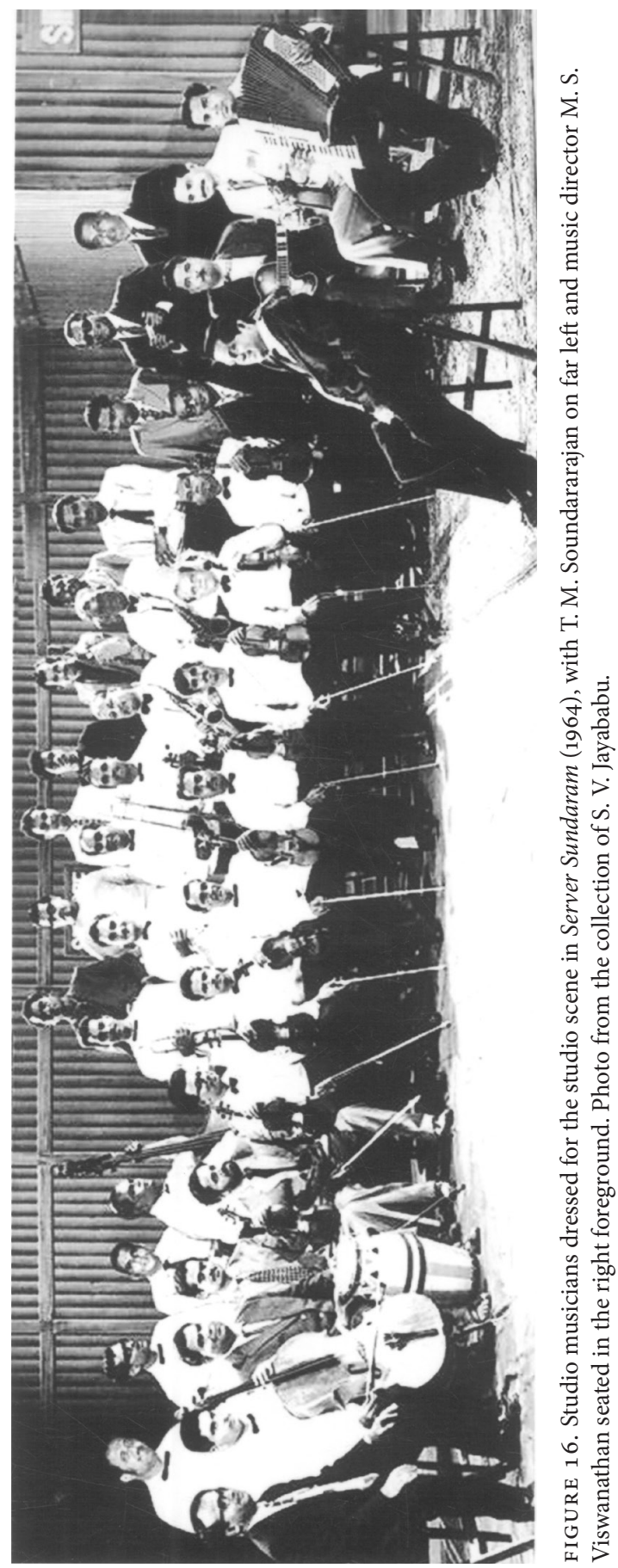


2007; Bates 2012). The domination of these new studio spaces by sound editing equipment, including large, elaborate consoles and computers and control-room windows that separate the recording engineer and music director from the singer, suggests the precedence of technical over musical knowledge.

The division between technical and musical labor has become accentuated in Tamil film music since the 1990 s as the work of being a music director has come to be more and more tied to mastery of digital sound editing. Unlike previous music directors, who left the technical recording and editing aspects to their sound engineers, for Rahman and the "new age" music directors who have followed since the 1990s, composing music requires an intimate relationship with the technology and editing software. Making a song now does not mean recording a performance so much as "comping"-building the song by combining bits and pieces of separately recorded tracks, often working with the minutest of cuts. This means that in terms of the spatial divisions of the studio, the music director now mostly occupies the control room rather than the performance space. Rahman, famous for having one of the most technically advanced sound recording studios and the largest sample library in Asia, is often portrayed seated at his console listening to tracks on his headphones, his star persona constituted through the aura of his studio (Meintjes 2003, 101).

Rather than being recorded in a single shift from start to finish, songs now come into being in a temporally and spatially fragmented process. The various people involved in making a song (music directors, sound engineers, lyricists, track singers, playback singers) are rarely physically copresent; communication of lyrics and sounds takes place instead by phone, email, and texting. Recording and processing material for a song takes place in different studios, some deemed better for instrumental or vocal recording, others for editing. A music director usually has several songs, often for different films, in process simultaneously, rendering the rhythm of work highly unpredictable..$^{17}$

Rather than having the status of a finished song, what the singer now records in the studio is treated as raw material to be shaped and structured by the technical expertise of the (male) music director and (male) sound and mixing engineers. ${ }^{18}$ "Singers don't know what the final song will sound like, what movie it will be in, or even whether it will be in the movie at all," one music director told me. As a recording engineer said, "Now you can record a track and go home, and I can sit here the whole night processing it, putting reverb, delay, cleaning it up-namma feel paṇni work paṇnalām [we can do whatever we feel like].” Whereas previously the playback singer's voice was relatively inviolable once recorded, it is now subject to ever more intensified forms of editing and manipulation in the dead space of the studio.

While the sprawling campuses of AVM Productions and Prasad Studios were city landmarks, these new studios rarely even announce their presence to the world outside. They are secluded spaces, interiors isolated not just by the physical 
barriers of doors and walls but by their very soundproofness, their deadness to the world outside. Even a prominent state-of-the-art studio such as A. R. Rahman's AM Studio, built in 2005, a white building located on a small street in a residential neighborhood in western Chennai, lacks a sign telling the outside world what it is.

Louise Meintjes has described evocatively how an aura of remoteness and exclusivity is generated around the post-1990s studio by its construction as a deeply interior space apart from the ordinary world, a "black box" set apart as unknowable (Meintjes 2003, 84-88). As Meintjes suggests, interiority is not just a physical condition but also a subjective and social effect, a "trope" $(2003,107)$ that finds expression in the physical space of the studio but also in the interiorized conception of the music director's creative process as something that takes place behind closed doors. The production and reproduction of this trope of interiority is "the source of the studio's efficacy as well as of its exclusionary and alienating potential" (Meintjes 2003, 107). Interiorization transforms the studio from being a public space, contiguous with the world outside, into a kind of private space, one that is not only physically closed off but also seemingly not governed by the same social rules as the outside world. The very construction of the studio as a "dead" sonic space, designed to isolate the sound being recorded from the sounds of the everyday world, makes it a space in which social rules are "ambiguous" rather than fixed or predictable (Bates 2012, 13-14). ${ }^{19}$ Amplifying the power relations set up by the physical configuration is the fact that recording studios are nearly universally controlled and inhabited by men and are thus marked as male spaces (see Bates 2016, 146-47).

The transformation of the studio from public to private, from a "live" to a "dead" space, has had a number of gendered social ramifications. A commonly heard lament is that this shift has caused the loss of both livelihood for male film musicians and the sense of a song as a collaborative project. But the deadness of the new studios has also been associated positively with increased technological sophistication, control, and flexibility, with freedom from older norms and constraints. The new studios are, and are imagined primarily as, youth spaces, the privacy effected by their "deadness" enabling a sense of being able to do things without elders looking over one's shoulder. Yet "youth" is a distinctly gendered category in India (Nakassis 2016; Lukose 2009), and the studio remains a resolutely male space.

The suspension of normal rules of social and gendered interaction in these settings produces an atmosphere of easy informality marked by tension. One evening in January of 2013, I was invited by P, a singer in her late twenties, to a recording session with a music director, J, who, though barely more than twenty years old at the time, had recently made it big with a hit song. Though $\mathrm{P}$ was well established as a singer, it was her first recording with J.

P says the recording will start at 6 or 6:30, and she will arrive at the studio by 5:45. I arrive at 6 , but we end up waiting nearly two hours in a small office room for J to get 
there. P seems perturbed about how late he is. She complains that no one wants to arrive on time because they feel they will just be waiting around.

When J finally arrives close to 8:00, he has his sound engineer, another young man, with him. He offers a quick, casual apology for his lateness, and then we go into the small control room. P writes down the lyrics for the song from J's phone in a spiral notebook. J jokes that he has forgotten the tempo of the song. They listen to the already-recorded instrumentals for the song, a sound like waves breaking, acoustic guitar, harp, flute, and strings, with a male track voice. The lyrics are about undying love. P asks if she can record it on her digital recorder so that she can take it into the room to practice with. J says, only half joking, "Sure, you can record and leak it out on YouTube!"

P goes into the performance room and practices there by herself. Meanwhile, three friends of J's arrive and crowd into the small control room, piling onto each other's laps. While $\mathrm{P}$ practices alone on the other side of the glass, they are engaged in a joking conversation about the songs in another movie, dictating a speech to be made at an upcoming audio launch, and ordering food.

$\mathrm{P}$ remains in the performing room for more than two hours, doing multiple takes while J expresses his satisfaction via the talkback button: "Super!" "Rocking!" At the end, after they have recorded line by line, he says, "I'll play the song from the top, and you just do whatever you want. Lyrics or humming. I'll take whatever is nice." By this time it is nearly 11 p.m. After the final take, P comes briefly into the control room. They listen to the takes once, and then she leaves. Feeling awkward hanging around with a bunch of young men at that hour of night, I leave too, thanking J for letting me watch. "Anyone can watch," he replies, gesturing lazily to his friends.

Multiple social norms have been contravened in this situation. Most obviously, it is a mixed-gender situation that takes place after normal work hours, extending into hours considered "late," especially for women. A young woman out alone after 10 p.m. unaccompanied by family members would be likely to encounter various forms of harassment. Normal age hierarchies are also reversed here; J controls the session, not in terms of the musical or technical aspects (in these there is an air of easy informality) but in social terms. Even though he is years younger than both his sound engineer and $\mathrm{P}$, and by rights should defer to them, it is he who arrives late, normally a privilege reserved for those of high status.

Distinctions between "public" and "private" are recursively reproduced in this strangely intimate space. J amasses a group of male friends in the control room whose joking male homosociality contrasts with P's solitary presence on the other side of the glass. His lazy manner, inviting "anyone" to watch, contrasts with the businesslike professionalism of $\mathrm{P}$, who remains on the other side of the glass, physically separated from the men in the control room for most of the evening. Yet, as with most cases of fractal recursivity, while the distinction itself is preserved, the content of the categories shifts (Gal and Irvine 2019). The solitary, "dead" space on the other side of the glass seems to offer a kind of privacy, but it is also a space in 
which $\mathrm{P}$ is highly audible and visible to the men on the control room side. Meanwhile, it is the exclusivity of the control room-its "privacy" - that allows J to create (and invoke) a group of male onlookers.

\section{HANGING OUT}

The spontaneity of musical creation in the studio is matched by an expectation that these spaces require social spontaneity as well. A voice conductor who had worked in the studios in the 1980 os told me that singers had a limited time to record songs; they would run through the song with the orchestra once and immediately record it. His onomatopoeic expression for "immediately" — "tak nu," literally, "as fast as one can say 'tak"'-reflects the regimentation of time and social relations in the old studio system. But the new studio environment requires that singers be able to operate in a social-interactional context that is unstructured and unpredictable. A young singer described the expectation among his generation that studio work would involve "hanging out":

Your attitude matters. . . . You need to be more friendly with people. Back in SPB [S. P. Balasubrahmanyam]'s time, people wouldn't care if they like the person or not. They need SPB-he is irreplaceable. Now it's not like that. We have so many options. So now, the girls, those that are . . brought up in . . typical Indian households, ... for them, getting along with men, basically the hanging out kind of concept does not work for them. They're like, I want to just go sing and get out. But that doesn't always work. You need to be friendly, you need to be in touch, to be hanging out. Like if a composer is going to work with me, I cannot tell him, "Dude, I'll come at 10:00 and I'll leave by 12." I have to give him his time. I'll come in at 10 and the lyrics might not be ready, he might want more things to be done, so I might have to hang out, sitting with him, chatting with him, finding out what he's up to and things like that.... So I don't know how many girls [can do that].

Whereas in the 1960s, 1970s, and 1980s, the use of various intermediaries-an "orchestra-in-charge," a man who called musicians and singers on behalf of a music director, as well as a "voice conductor," a man who mediated between music director and playback singers in the studio-preserved a certain distance between music directors and singers, the ideal now is direct contact and informal relations. Subha described the progressive erosion of social distance among singers and music directors in the studio, encapsulated in the transition from the formal, Sanskritic greeting "namaskaram," to the friendly English "hi," to the swaggering Tamil slang "maccān" (brother-in-law, "dude”), an informal term of address associated with youthful male sociality: ${ }^{20}$

In those days [the 1980s and 1990s] I'd say "hi." The generation before me would say "namaskaram." I was a "hi" person. The generation now is like "Maccā-how are you sweetie pie!" and lots of tactile contact. ... And parameters-we definitely had a fence which nobody could [cross].... We'd never socialize you know. Once we 
finished our work, we'd come back. Nowadays once the work is over they'll go out to a pub or they generally chill out. More than a music director or a singer, they're friends, pals these days. A huge shift has happened. Now there are cliques. It's like, you hang around, and if you get a song, you get a song. In a studio, you have an office outside. The music director will come and say, "Hey maccā where are you da, I need a couple of voices."

In those days, an orchestra-in-charge called, you went at a particular time, learned the song, you went inside and finished your work and came home. There are some people who still call like that, but the general ambience has changed. Someone told me some singers, a gang of them, went to Bangkok for a composing session, four girls and four guys. [They] went there and for three or four days they are chilling over there and any time the music director wanted a guide track- "just sing this so I can see what it sounds like"-he'd call them. In our day there would be no chance for this. I don't think we'd be allowed back into our homes again!

In emphasizing the impossibility of return from such a trip to the norms of domestic/family life, Subha's statement highlights the fact that the refiguring of both stage and studio as places of greater spontaneity and freedom renders them uniquely risky for women. While older gendered hierarchies may be muted in these spaces, so are many of the safeguards they provided for women working within a male-dominated environment; hence, women's presence in these spaces now runs the risk of being sexualized in ways that it had not before.

Some weeks after the recording session described above, I observed another session with a palpably different dynamic. I had met a singer, $\mathrm{C}$, at the studio where she was recording that afternoon. Though $\mathrm{C}$ was about thirty, the music director was much younger, barely more than twenty. His engineer and two or three other young men were also present:

In the control room, the music director, engineer, and $\mathrm{C}$ listen together to the already recorded track of the male singer. The music director explains the situation: the hero is expressing his love to the heroine and she is replying. In the recording room, $\mathrm{C}$ finds the pitch of the song too high for her voice, a common problem for female singers because the songs tend to be composed around the capabilities of male singers. After trying different timbral strategies to solve the problem, $\mathrm{C}$ asks to do it an octave lower. The music director agrees, and they record the song this way, finishing within half an hour. She comes into the control room, and as they listen to the recorded takes she advises the music director that he will have to keep the focus on the female voice; otherwise, it will get lost. She asks who the actress will be and whether it is a lip-sync song, and tells him to add some low, heavy strings at the end of the song.

Chatting with me later, $\mathrm{C}$ remarked that while this was a very comfortable session in which she was able to advise the music director, not all were like that: "In some recording sessions it'll be like you with ten guys watching you like a hawk. Some music directors are very strict about how they want the song and don't give you any chance to give suggestions at all. . . Others are so casual, it's just a guy 
and a computer, and you don't even know when or if they're doing a take." Both the homosocial male publics created within the intimate spaces of these studios and the technologically deadened scenario of "just a guy and a computer" had the potential to create a situation in which a female singer's presence in the studio could be sexualized. In addition, the presence of so many young music directors these days, $\mathrm{C}$ said, made the work unpredictable. "See, when I walk into the studio, I have to gauge the vibe of the environment and the people who are there, because a lot of times I have never met them before if they are first-time music directors. The energy I get, I try to take it from there."

As $\mathrm{C}$ described it, the burden was on her to determine the nature, and limits, of her participation. She explained to me that her suggestions to the music director in this session were meant to control the reception of her voice-to make sure singing in such a markedly low female register would be successful and not be "taken the wrong way." And even though she had a reputation as an "interactive performer" who was at ease hanging out in the new environments of the stage and studio, she had to maintain a limit on the explicitness of the lyrics she was given to sing. "They shouldn't be really explicit for no apparent reason," she explained. "One time, a music director had called me to do a song, and the lyrics were like, 'Hey, dude, your veshti has a big stain on it. What's that?' So there's no way I'm going to sing that!"

\section{ANXIETIES OF EMBODIMENT}

Since the 1990s, as I have suggested here, "liveness" onstage and the "deadness" of the studio have come to be valued and cultivated. Both are associated with getting rid of constraints, a liberating break from the old social order. But along with them come demands for forms of embodied presence: "rocking the stage" and "hanging out" in the studio. As they naturalize forms of self-presentation and sociality most easily enacted by men, the live space of the stage and the dead space of the studio leave women in a distinctly precarious position, hovering between permission and prohibition, engaged in the delicate work of negotiating situations in which their presence may at any time be rendered awkward or even obscene. In this new dispensation, liveness and deadness produce anxieties about embodiment that must be assuaged by careful acts of framing, qualification, and distinction-for example, having an MC announce a singer as "the kind who dances as she sings," changing from a floor-length gown to a miniskirt to perform an item number, or using the studio setup to physically separate oneself from a group of male onlookers.

The concept of enregisterment is useful here, beyond its linguistic origin, to describe the way that tangible, sensory qualia can be bundled together in recurring ways to signify a larger concept. Crucially, enregisterment is a relational process; a style or concept can only become enregistered when it is placed in contrastive relation to other styles or concepts within a semiotic economy. In 
playback's old performative dispensation, liveness and deadness came to be enregistered primarily through indexical gestures that pointed to different kinds of female public appearance: sexualized display and respectable, controlled female performance. In the post-liberalization dispensation, liveness and deadness have been reenregistered through new indexical gestures that seek to overlay the old, pointing instead to a new chronotope of creativity, spontaneity, freedom from constraint, technological sophistication, and "global" horizons. But this overlay of the new over the older order is incomplete, only ever partially successful, for the very indexical gestures meant to point to the new chronotope can instead point back to older enregistered distinctions.

Two gendered figures have emerged to define the extremes of this new and unstable semiotic field. One is the male music director, master of both the deadened space of the studio and the livened space of the stage, projecting technical wizardry and rock-star aura in place of the hierarchical male sociality of the old studios and the corporate masculinity of the light music troupe. The other is the female MC, whose labor is required to simultaneously produce and tame the liveness of the stage in these new settings. And even when she herself is not present, her enregistered "voice" continues to perform this labor. For female singers, distancing themselves from the nonemotive, nonauthorial deadness of female respectability requires using the chatty, lively register of the $\mathrm{MC}$, channeling the particular way in which she transgresses earlier notions of proper onstage female comportment. A surrogate who tames the unruly potentials of women's presence onstage, and a symptom of the very problem she is meant to contain, the MC's manic speech registers the anxieties and desires that accompany the increased exposure and sexualization of female singers in the post-liberalization era. 